DOI : 10.24260/khatulistiwa.v8i1.1278

\title{
ISLAM AND LOCAL INTERESTS IN THE SAFAR BATH TRADITION OF MALAY PEOPLE IN SUNGAI JAMBU SUB VILAGE, KAYONG UTARA
}

\author{
Dewi Nurhayati \\ Pontianak State Institute of Islamic Studies \\ Email: dewinurhayaty23@gmail.com
}

\section{HIGHLIGH}

- Islam and Local's Wisdom

- Mandi Safar (Safar Bathing)

- Kayong Utara's Malay

- Sungai Jambu

\section{ARTICLE HISTORY}

$\begin{array}{lll}\text { Submitt } & : & 05 \text { Mar } 2018 \\ \text { Revision } & : & 24 \text { Apr } 2018 \\ \begin{array}{l}\text { Revision } \\ \text { Minor }\end{array} & : & 2 \text { May } 2018 \\ \text { Accepted } & : & 5 \text { May } 2018 \\ \text { Published } & : & \text { 01 Jun } 2018\end{array}$

\begin{abstract}
Malay people are known to have diverse traditions as ancestral cultural heritage. One of the Malay cultural heritages of Sungai Jambu sub vilage is the form of a Safar Bath Tradition which is believed to be an effort to avoid being bala. Safar baths that are held every Safar Month are followed by the Malay Community of Sungai Jambu Sub village, both men and women and elders and young people. This article explains that Islam and the elements of local wisdom play an important role in the Tradition of Safar Baths. In fact there has been a mixture of Islam and local wisdom in the Safar Bath Tradition. The community believes that the tradition can prevent or even eliminate all kinds of bad luck, disaster or future calamities. Likewise, if implemented it will avoid reinforcements and diseases.
\end{abstract}

Keyword : $\quad$ Islam, Local Wisdom, Safar Bath Tradition.
KHATULISTIWA: Journal of Islamic Studies Vol. 8, No. 1. March 2018
DOI: 10.24260/khatulistiwa.v8i1.1278

Islam and Local Interests in The Safar bath Tradition of Malays People in Sungai Jambu Sub Vilage, Kayong Utara 


\section{A. INTRODUCTION}

The tradition of Safar Bath is widely discussed in Muslim societies. According to Natsir (2007: 33) the origin of Safar Baths was taken from several events experienced by the previous Prophets that occurred in the month of Safar, such as the rescue of Noah's ship from the danger of flooding, the avoidance of Prophet Ibrahim from fire, and the escape of Prophet Moses and Aaron from the kingdom Pharaoh's army by splitting the red sea.

Moeslim Abdurrahaman (in Bahtiar et al., 2008: 155) mentions that there are pros and cons about this in the community. On the one hand there are those who regard it as an act of heresy which should not be done because it contradicts with the teachings of Islam which forbids superstition and reconciliation and contains elements of shirk, while there are those who argue that the Safar Bath Tradition is merely an ancestral tradition that breathes Islam by prioritizing Islamic modification and discarding elements of mysticism, or in other languages "Islamizing local traditions or culture".

The emergence of pros and cons according to Simuh (in Nurozi, 2016: 128) originated from two camps that were always at odds even leading to internal friction among Muslims between the Islamic orthodoxy movement and the indigenization of Islam in seeing Islam vis a vis local traditions. Islamic orthodoxy or purification of Islam is used by those who try to separate clearly one is which rights and which one is wrong according to their version without any tolerance, and place Islamic teachings as formal teachings that need to be applied as they are in accordance with their understanding and interpretation of the Koran and hadith. This approach was used when the teachings of their version of Islamic monotheism were dealt with the understanding of mythology which they thought smelled of superstition and superstition. Whereas the indigenous approach of Islam or accommodative-reformative is an approach that captures the moral ideal of Islam than its formal legal aspects. Islam is understood contextually, and it is respected, flexibility by local cultures.

A cultural expression of people is belief in something sacred of faith in the Almighty. If the relationship between religion and tradition is placed as a form of interpretation of history and culture, then all religious domains are human creativity that is very relative in nature. Its means that the truth of the religion is believed by everyone to be "right" and it is basically limited to what can be interpreted and expressed by humans who are relative to God's absolute "truth". Thus, whatever form is carried out by human attitudes to maintain, renew or purify religious traditions, it must still be seen as a struggle in the dynamics of the history of the religious community itself.

Every community has a variety of cultures and traditions, where it various diversity has become a characteristic of an area. As for examples in Indonesian society, one of them is the Safar Bath Tradition. According to Bahtiar, et al (2008: 85) the tradition of Mandi Safar in Air Hitam Laut Village, Sadu District, East Tanjung Jabung Regency can prevent or even eliminate all sorts of misfortunes, outbreaks of infectious diseases, disasters or calamities that will or have come, especially in the month of Safar.

Hasan (2012: 289) revealed the acculturation of culture to produce a unique religious pattern, although some religious rituals were negative. The negative culture that has been

KHATULISTIWA: Journal of Islamic Studies

Vol. 8, No. 1. March 2018
DOI: 10.24260/khatulistiwa.v8i1.1278

Islam and Local Interests in The Safar bath Tradition

of Malays People in Sungai Jambu Sub Vilage, Kayong

Utara 
maintained until now is the refusing ceremony, including Wednesday Abeh or Mandi Safar. The rebellion ceremony is held on the last Wednesday of the month of Safar. They believe that the Safar bath can bring syafa'at if it is implemented, and it will bring harm. Wednesday Abeuh was carried out to drive away evil spirits, because he could destroy society.

From the statement of the above opinion, Abdullah (in Bahtiar et al., 2008: 102) states that Safar Bathing is like other traditions that develop in the community, although it seems to be a tradition that has a religious nuance, but basically the tradition is not part of religion. Islam through the Qur'an and hadith was never ordered to carry out the Safar bath. Therefore, in the Safar bathing ceremony which needs to be put forward, the "tradition and culture" aspect is not an aspect of its religious ritual. Because if the Safar Bath is considered a religious ritual, it is feared that it will give rise to an understanding among the community that Mandi Safar or the verse that heals, saves, and avoids people of all kinds of disaster and disaster.

\section{B. METHODS}

The study of the safar bathing tradition is qualitative research. Data is collected in Sungai Jambu, North Kayong. This place, in the southern part of Pontianak City. The distance from Pontianak is approximately 20 hours drive by water motorbike and continued by road trip. Sungai Jambu was chosen because as far as the researchers know, that it has a unique culture and some traditions are still carried out. One of the typical traditions that is still practiced is the safar bath.

Data was collected through interviews and documentation. Interviews were conducted with community leaders and cultural actors. They are considered to know the ins and outs of safar bathing activities and can explain the information needed by researchers. In addition, documentation of the activities of the researchers explored by getting photos of activities; both private property and private documentation that has been published in public spaces. Data that can be obtained by researchers in the field are then processed qualitatively and conclusions drawn.

\section{RESULT AND DISCUSSION}

\section{General Description of the Community of Sungai Jambu Sub village}

Dusun Sungai Jambu is located in Kayong Utara District, West Kalimantan. This region is at the South side of Capital City of West Kalimantan Province. According to Datuk Abdul $\mathrm{Mu}$ 'in, adat leader and religious leader, this village is called Sungai Jambu sub village because it used to be on the banks of the river with many guava trees. Therefore, it is called Sungai Jambu sub vilage.

According to data available on Muhammad Junaidi, Head of Sungai Jambu sub village, the population of Sungai Jambu Sub village is 562 people from 210 households (KK), 555 Muslims and 7 Buddhists. The Work of the Malay Community in Sungai Jambu Sub village varies. As many as $50 \%$ works in oil palm plantations, $30 \%$ are farmers and $10 \%$ are fishermen.

KHATULISTIWA: Journal of Islamic Studies

Vol. 8, No. 1. March 2018
DOI: $10.24260 /$ khatulistiwa.v8i1.1278

Islam and Local Interests in The Safar bath Tradition

of Malays People in Sungai Jambu Sub Vilage, Kayong

Utara 
The Malay community of Sungai Jambu Sub village includes people who are still strong in practicing local customs. Trust in supernatural power is still held by many people. That is one reason why the tradition of Safa $r$ bathing can still be found here.

\section{Local Wisdom and the Tradition of Safar Bathing}

Human life is surrounded by culture and tradition. This is because humans always try to maintain their existence in life which requires them to always be in contact with the surrounding environment, both physical and non-physical environments. The process of forming culture lasts for centuries and it is tested so as to form a component that is reliable, proven and believed to be able to bring physical and spiritual well-being.

Culture was born thousands of years ago since humans were on Earth. Habits that have become and shape human behavior are inherited from generation to generation, taking into account their environment and their future interests, making them different from humans elsewhere. That's why there is manifest local wisdom.

Widjajaputra (2008: 2-3) acknowledges that it is sometimes difficult to identify forms of local wisdom found in a community, especially after long-distance communication devices that have developed in such a way that relations between local communities in various regions of the earth are very easy. Interaction between communities has given birth to various forms of system locality and its new set of tools. The meeting of ideas, theories and methods between communities has given rise to a new form that can be in the form of wisdom. Moreover, the natural conditions and social environment have changed in such a way with a relatively similar pattern in various parts of the world, which of course will encourage the emergence of new wisdom that is relatively the same between communities even though they still reveal their own peculiarities.

According to Prasojo (2017: 2) local cultural values in various regions in Indonesia can function as a model to restore the direction of locality-based development that fits every community. Local wisdom can be a social capital in developing a national attitude that needs to be maintained, because local wisdom is part of the culture of the community. This has become a potential wealth of the nation which also needs to be preserved as a diversity that is the source of the nation's wealth. One of them is the tradition of safar bathing as a spiritual effort towards a self-approach to Allah carried out by some Muslim communities in several regions in Indonesia.

Yusriadi (2016: 1-2) argues that local wisdom also needs to be explored and promoted so that it can become learning for other communities. Learning from the local wisdom of a community is useful for other communities because the values of local wisdom are definitely something that has been tested by time and space. Therefore there is no doubt that local wisdom can be a model in people's lives.

Muslims, in this context, must really look smartly at the other side of the existing culture from various perspectives, be smart in seeing the situation of a cultured society so that it is not easy to pass or consider something negative, such as an assessment of a culture

KHATULISTIWA: Journal of Islamic Studies

Vol. 8, No. 1. March 2018
DOI: 10.24260/khatulistiwa.v8i1.1278

Islam and Local Interests in The Safar bath Tradition

of Malays People in Sungai Jambu Sub Vilage, Kayong

Utara 
is bid'ah. (Marzuki, 2016: 219). God has taught us through his word in the Koran to learn something thoroughly, not only in terms of the Tabut also the implicit value which has further knowledge. This is mentioned in the Qur'an in the Surah Shaad verse 29 below, Meaning: "This is a book that We send down to you full of blessings so that they pay attention to His verses and to get lessons from those who have thoughts."

Aibak (2010: 1-2) states that in Islam there are eight months which are declared as holy months, namely the month of Muharram (Suro), Safar (Sapar), Rabi'ul Awwal (Mulud), Rajab (Rejeb), Sya'ban ( Ruwah), Ramadhan (Poso), Dzulqa'idah (Selo), and Dhulhijjah (Great). In those months Muslims, especially Indonesian Muslims, carried out many rituals or celebrations to commemorate them, and indeed in eight months they had important meaning so they must be commemorated. Through the warning or celebration, the connection with identity as Muslim is expressed through certain symbols. The significance of these months is more traceable in Islamic history than in the scriptures. The general pattern of warning or celebrations composed of one or a combination of various elements, such as fasting, praying, prayer suna h, reading the Koran, read the history of Muslim figure or stories concerning the glory of those months, teaching and serving of food or other objects as symbols of celebrations.

About eight months declared sacred, especially one of which is the month of Safar, the moon is considered a tradition which was stated by Muhammad Arsyad As'ad (in Baht iar et al, 2008: 93) that practice is similar to Mandi Safar told by a great scholar named Sheikh Muhammad bin Alwi al-Maliki al-Hasani, in his book Abwab al-Faraj ha page 63 article treatment with syifa verses, which tells that al-Imam al-Sheikh Abu al-Qashim al-Qusyairi Rahimahullah, his son was sick until to the point that he almost despaired to see the condition of his child, then in his sleep he dreamed of meeting the Prophet, then he complained about the condition of the child.

Then the Prophet said: "Don't you know that the syifa' verses that are in the Qur'an?" Then Imam al-Qusyairi immediately looked for the verses referred to by the Prophet. And six verses in the Koran which contain the word syifa are found, namely those found in surah atTawbah 914), Yunus (57), an-Nahl (69), al-Isra (82), and al-Syu'ara (80) . Then al-Qusyairi wrote the verses on paper and put them in the water and presented them to his son to drink as an antidote, then healed the child from his illness.

Different things stated by Aditiya (2015: 7) that the verses of the Koran are surah Yasin (58), ash-Shafat (79), ash-Shafat (109), ash-Shafat (120), ash-Shafat (130) , az-Zumar (73), and al-Qadar (5) in the Safar Bath Tradition in Sungai Buluh Village, Singkep Barat Subdistrict, Lingga Regency, Riau Islands Province, write these verses on wafaq. Before writing it on wafaq, the conditions that must be fulfilled when writing seven verses are as follows: Must be done on Friday night because the community believes that on that night someone will be made easy by Allah SWT . Wudu is performed to restore one's sacredness from unclean things so that at the time of writing wafaq the heart becomes calmer, the Prayer of the circumcision of Tahajud is recommended for the prayer of the Sunajat Tahajud to ask for guidance from Allah SWT.

KHATULISTIWA: Journal of Islamic Studies

Vol. 8, No. 1. March 2018
DOI: $10.24260 /$ khatulistiwa.v8i1.1278

Islam and Local Interests in The Safar bath Tradition

of Malays People in Sungai Jambu Sub Vilage, Kayong

Utara 
Arsyad (2005: 3) states that the seven verses referred to in the book Tajul Muluk are in the surah Yasin (58), ash-Shafat (79), ash-Shafat (109), ash-Shafat (120), ash-Shafat (130), az-Zumar (73), and al-Qadar (5).

Sheikh Syafruddin (in Khoiri, 2017: 202) states that seven verses from the Koran are then drunk with the intention to get good and barakah. A different thing is stated by Chalik (2016: 21) as for the religious basis in the perspective of scholars' opinions about before every month Safar Allah bring down thousands of bu bala. Therefore the previous scholars made slametan (praying and giving sadoqah food) and praying on Wednesday the last of the Safar bulls to be free from the plagues, the calamity and the punishment that was revealed by God.

Whereas according to Siti (2012: 85-86) the belief in the Safar Bath Tradition is not a religious teaching but only customs and traditions, because it is not discussed in the Qur'an and Hadith, but some of them argue that working on the traditions above is their effort to adjust and be accepted by the surrounding environment. This month is named 'Safar', related to some of these meanings, in which the Arabs at the time of Jahiliyah first departed to wander. They left their residence in the month so the houses became empty (رفص ); and at one time they had departed to coincide with summer and dry, when the leaves became yellowish (رفص ); and many sufferings and disasters experienced by them (رفص If traced further it turns out that the belief in the misfortune in the month of Safar has existed long ago among the Arabs. It was stated that on the last Wednesday (arba mustamir) on the safari month each year fell three hundred and twenty thousand $(320,000)$ reinforcements. It was the hardest day of the year, these reinforcements were then spread in the days of the year.

Based on the background of the socioculture of such Jahiliyah Arab society mentioned above, Ra sulullah SAW , said :

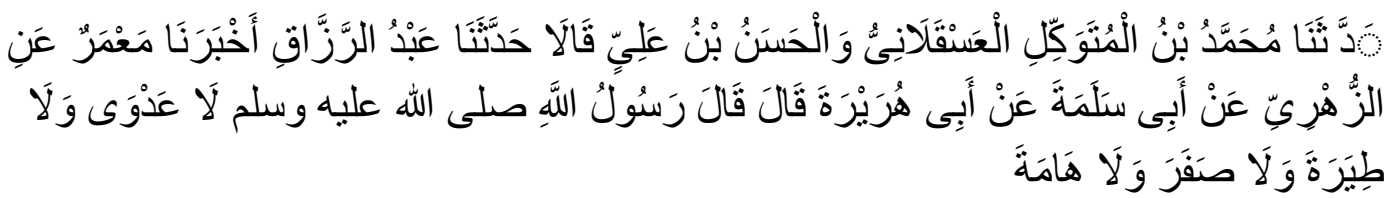

Meaning: Telling us Muhammad bin All-mutawakkil Al-Asqolani and Hasan bin Ali, they both said; 'Abdurrazaq and Ma'mar told us from Az-Zuhri from Abi Salamah from Abi Hur airah said; Ra sulullah SAW said: There is no contagious disease, there is no (belief that) the bones of the dead will become birds, and there is no safar month (bad luck month). (Sunan Abi Dawud: 2015: 488)

The same thing was stated by Albani (2006: 210) regarding infectious diseases, as follows:

"From Abu Salamah Bin Abu Rahman From Abu Hurairah ra, when the Prophet sallallaahu 'Alaihi Wa Sallam said there was no contagious disease (without Allah's permission) there was no taboo on the Safar Month, and no corpse became a ghost, then

KHATULISTIWA: Journal of Islamic Studies

Vol. 8, No. 1. March 2018
DOI: $10.24260 /$ khatulistiwa.v8i1.1278

Islam and Local Interests in The Safar bath Tradition of Malays People in Sungai Jambu Sub Vilage, Kayong Utara 
a Bedouin Arab asked, O Messenger of Allah, what about the camels in the healthy desert how deer. After that, a scaly camel came along and then infiltrated the middle of the healthy camel so that everything became scurvy? The Prophet sallallaahu 'Alaihi Wa Sallam answered who issued the disease for the first time. The Prophet sallallaahu 'Alaihi Wa Sallam said "there is no contagious disease without Allah's permission.

In the implementation of the Safar Bath Tradition in which there are readings of prayers , prayers for repelling bala and Andung-andung leaves are written with Qur'anic verses called Salamun Tujuh (seven welfare). The effort to cultivate the aqeedah that wants to be addressed is the conviction and sincerity that there is no other purpose in life and nothing else can be worshiped except Allah SWT ., as the word of Allah SWT ., in the Kor an surah Ali-Imran verse 62, Meaning: "Indeed this is a true story, and there is no God (who has the right to be worshiped) other than Allah; and Allah, He is the Mighty, the Wise.

People who pray during the Safar Bath Tradition is to maintain personal safety from reinforcements and diseases. As the word of Allah SWT , in the Qur'an surah al-Mukmin verse 60 which reads: Meaning: "And your Lord said:" Pray to Me, I will allow you

The same thing was stated by Khoiri (2017: 204) as a weak and always needy servant, instructed to even become a necessity to always pray. The Tradition of Safar Bathing, as explained by Muhammad As'ad Arsyad (in Bahtiar et al., 2008: 101) indeed there is no legal basis. Therefore, the Tradition of Mandi Safar is not an Islamic tradition or teaching. But more on the traditions of some Islamic societies, especially in Indonesia. Because of its tradition, it may be packaged in such a form, as long as it does not deviate from the Islamic faith.

Muhammad Said Magwie (in Bahtiar et al, 2008: 101) explains that the tradition Mandi Safar is a prayer for safety effort embodied in the traditional practice, such as drinking and bathing with water containing a prayer. The Prayer of Mandi Safar which contains seven verses of the Koran, all of which begin with "salamun", aims to invoke salvation. Some of the Safar Bath Prayers were written, some were read directly, even memorized. Reading the Qur'anic verses is aimed at invoking syafa'at, pleading with hope and optimism, in the language of religion known as "tafa'ul". Bathing and drinking with verses are only intermediaries, but the one who heals is Allah SWT .

Furthermore, according to Muhammad As'ad Arsyad (in Bahtiar et al., 2008: 92-93) that one of the sources held so far is the expression of Sheikh Syarfuddin in his book "Ta'liqah" which explains that on the last Wednesday night of the safari month, Allah SWT reduces twelve thousand kinds of reinforcements (disasters in the form of natural disasters or epidemics or trials) from the lauhul mahfudz to the sky of the world. So to avoid the various kinds of reinforcements, he wrote seven verses from the Koran then drank with the intention to obtain goodness and blessing. As quoted from the book "Taj al-Mulk" p. 7l, the article Prayer Bathing in the Safar Month. From the statement, that human are still obliged to endeavor and try to avoid all calamities in the month of Safar.

Therefore, the Safar Bath Tradition is considered a tradition that is packed with elements of the Islamic religion. However, from the implementation of the Safar Bath, the local

KHATULISTIWA: Journal of Islamic Studies Vol. 8, No. 1. March 2018
DOI: 10.24260/khatulistiwa.v8i1.1278

Islam and Local Interests in The Safar bath Tradition of Malays People in Sungai Jambu Sub Vilage, Kayong Utara 
community when bathing in the trenches, some of the women used kemban without covering their genitals and some of them were covering the genitals. Likewise, there are men who use trousers (some are covered in navel and some are not, thighs and knees are closed) and shorts without wearing clothes, but there are also those who wear clothes and pants when taking Mandi Safar.

\section{RESULT AND DISCUSSION}

The Mandi Safar tradition on the Jambu River in North Kayong Regency, has been handed down for generations by the Malay Community of Sungai Jambu Sub village because it is believed to be an attempt to reject reinforcements in the Safar month. As with other communities mentioned above, the month of Safar is believed to be a month that contains a lot of reinforcements. Therefore, Safar Baths are intended to cleanse themselves to avoid reinforcements or disease.

In the Malay community of Sungai Jambu Sub village, the tradition carried out in the second month of the Hijri calendar is closely related to Islamic culture. Although not included as an obligation in Islamic law, the Tradition of Safar Bath is very thick with Islamic nuances.

According to Datuk Mu'in as adat leader and religious leader of Sungai Jambu sub village, North Kayong Regency, the origin of the emergence of the Safar Bath Tradition originated from the people's belief in the disaster or the disaster in the month of Safar (collision or accident). In addition, the Tradition of the Safar Bath was carried out to follow the instructions of the Prophet Muhammad while spreading Islamic da'wah, his preaching was blocked by unbelievers who had the intention to kill him. At the time of the assassination plan Prophet Muhammad sallalla Alaihi Wa Sallam hid in Gua Hira in the month of Safar and read seven verses of the Koran or so-called Salamun Tujuh (seven welfare) and after reading the verse Prophet Muhammad sallallaahu 'Alaihi Wa Sallam disappeared or with the word other infidels do not see the Prophet Muhammad sallallaahu 'Alaihi Wa Sallam in Gua Hira.

Regarding some of the opinions above, that the last Wednesday in the month of Safar was an important day for the Malay people of Sungai Jambu Sub village, North Kayong District, so the tradition of Safar Baths needed to be carried out. In this day the tradition of Mandi Safar is still done.

It is not yet clear the origin of the last Wednesday taking in the month of Safar to be used as the day of carrying out the Safar Bath Tradition. It's just that, Allah SWT , down 320,000 reinforcements every year and most of them were revealed on the last Wednesday of the safari month. Starting from the belief in past events and the number of reinforcements that fell on the safar month, then some traditions are carried out to take lessons from experiences from the past while avoiding the coming of reinforcements. The Safar bathing tradition carried out by Malay people in Sungai Jambu Sub village, North Kayong District, is one way to avoid the bala.

On that day, the Malay people of Sungai Jambu Sub village who will do the Safar Bath Tradition do not do the work as usual. They only waited until the time of Mandi Safar arrived,

KHATULISTIWA: Journal of Islamic Studies

Vol. 8, No. 1. March 2018
DOI: $10.24260 /$ khatulistiwa.v8i1.1278

Islam and Local Interests in The Safar bath Tradition

of Malays People in Sungai Jambu Sub Vilage, Kayong Utara 
while preparing all the equipment for the Mandi. The tradition of Safar baths is carried out in small trenches, as well as in the house (bathroom). Sometimes before deciding to determine a Safar Bath, a community meeting is held first. In the meeting it was decided to designate a specific location as a place to hold Safar Baths.

Tradition of Mandi Safar as well as we know is not in Islam teachings in the Koran and the Prophet's Sunna. In the tradition of Safar Bath by the Malay Community of Sungai Jambu, some of the people believe in the existence of reinforcements and diseases in the month of Safar. However, after the researchers interviewed Datuk Mu'in and Mariana as the customary religious leaders, they said that the Sungai Jambu sub village residents stated that if the tradition of Mandi Safar would not be carried out would contain reinforcements and diseases on the other hand it would protect from disease and illness. In addition, according to Mu'in and Mariana the implementation of the tradition of Safar Bathing as a preservation of culture which is hed once a year the Safar month.

\section{Equipment of the Safar Bath Tradition}

According to Datuk Mu'in as the customary leader and 60-year-old religious figure that before the implementation of the Safar Bath Tradition, several tools were prepared as follows: Leaves of Andung- andung. It's a plant that grows a lot in West Kalimantan. This wideshaped leaf is then written with Arabic script taken from the verse in the Qur'an called Salamun Tujuh (seven well-being). In addition to being used as an ingredient in Mandi Safar, Andung-andung leaves are also used as ingredients in reinforcing reinforcements in the Malay community of Sungai Jambu sub village.

Pencil. Used to write seven verses of the Koran (Salamun Tujuh or seven well-being) in the Andung-Andung leaf section. But before writing first read Al-Fatihah once. Clean water is prayed by religious leader before that people drink it. The prayed water is aimed to maintain persona safety. The clean water is used for bathing. This water is intended as a mean to cleanse it some one disease and bad things.

Ketupat is released (using pulut rice or sticky rice and rice). This food is used as a complement because Safar Bath is a tradition in which many people gather to do the tradition of safar bathing, starting from the family, and immigrants or comers. As a medium of interaction, usually Safar bath participants will offer each other ketupat to the participants of Mandi Safar. You could say the Safar Bathing procession was started in the morning around 7:00 a.m. on the last Wednesday of the month of Safar. After the morning pray, the people who will carry out the Safar Bath Tradition prepare all kinds of equipments and prepare for the mosque which has been used as a gathering place for the Malay people of Sungai Jambu sub village, both in groups and individuals.

KHATULISTIWA: Journal of Islamic Studies

Vol. 8, No. 1. March 2018
DOI: 10.24260/khatulistiwa.v8i1.1278

Islam and Local Interests in The Safar bath Tradition

of Malays People in Sungai Jambu Sub Vilage, Kayong

Utara 


\section{Implementation of the Safar Bath Tradition}

Interviewing with Datuk Mu'in that before carrying out the Safar Bath tradition, the Malay Community of Sungai Jambu Sub village, North Kayong District, prepared to take the leaves of the Andung-andung, it is one day before carrying out the Safar Bath tradition. Andung-danung leaves that have been taken both planted in front of the house or in the funeral waqf are then delivered to the house of the adat leader (also acting as religious leaders) namely Mu'in and religious leaders by Datuk Sunul with the aim of the Andungandung leaves written verses of the Qur'an or Salamun Seven by using a pencil slowly so that the leaves are not perforated by the customary leader and the religious leader. However, before writing the verse, you have to read surah Al-Fatihah once.

Andung-andung leaves that are delivered to the house of the adat leader (also as religious leaders) and representatives of a few people because it depends on the willingness of the local community and religious leader, but on the contrary if the local community does not take Safar baths in the bathroom and Safar baths in the ditch, the leaves of the Andungandung are written and the leaves are tied using bamboo and plugged into the trench right in front of the mosque or in front of the local community.

After the last Wednesday of the last Sunday of the month of Safar, the Malay Community of Sungai Jambu Sub village, Kayong Utara District held a meeting at the mosque carrying leaves of Andung-andung, clean water and loose ketupat (using sticky rice and true rice). Clean water is also not all Malay communities in Sungai Jambu Sub village carry the water. Because it depends on the willingness of the local people to take Safar baths at home or in the bathroom, they must bring clean water and Andung-andung leaves written by Seven Salamun, which must be put into the water for those who carry Safar Baths at home and those who do not carry in the ditch provided that the water in the ditch has been plugged in by the andung-danung leaves and written Salamun Tujuh.

Then, the clean water that has been brought is placed on the mat because it makes it easier for the adat leader and religious leaders to read surah Al-Fatihah once and then read surah al-Ikhlas, surah al-Falak and surah an-Naas once. After reading the surah al-Ikhlas then reading Laa Ilaaha Illallaah Wallahu Akbar once and continued with the recitation of surah al-Falak and continued with the same reading Laa Ilaaha Illallaah Wallahu Akbar and reading the surah An-Naas. Then read surah al-Fatihah. The water that has been read the prayer may also be drunk either after or before Bathing Safar. Here, religious leaders and adat leaders have the same role.

When the prayer have completed, the loose ketupat brought by the Malay Community of Sungai Jambu Sub village eats together in the mosque and is shared with each other. The last of the joint meals was the implementation of Safar Bath by the local community. Safar Bathing Process begins with the intention "Ask help the reinforcements and to keep from the evil one begging to Allah SWT " and only carried out on one day, Wednesday the last Sunday of the Safar month.

KHATULISTIWA: Journal of Islamic Studies

Vol. 8, No. 1. March 2018
DOI: 10.24260/khatulistiwa.v8i1.1278

Islam and Local Interests in The Safar bath Tradition

of Malays People in Sungai Jambu Sub Vilage, Kayong

Utara 
The implementation of the Safar Bath Tradition by the Malay Community of Sungai Jambu Sub village is certainly a quite interesting religious and cultural phenomenon. The uniqueness of the Tradition of Safar Baths is that if the pregnant woman gives birth in the month of Safar and then the mother and baby. On the one hand, the beliefs of the Malay people of Sungai Jambu Sub village towards the month of Safar contain a lot of and if they are not carried out, they will bring disease. However, in other contents it is a form of gratitude to Allah SWT by saying the surah contained in the Koran along with prayers and as a preservation carried out from generation to generation by the Malay Community of Sungai Jambu Sub village, North Kayong Regency. Based on this phenomenon, the Safar Bathing Tradition is interesting to be studied more deeply about what the urgency of Mandi Safar is, in terms of Islam and local wisdom.

\section{Symbol in the Safar Bath Tradition}

According to Datuk Abdul Mu'in as the customary leader and religious leader of Sungai Jambu Sub village that the symbols or meanings of the Safar Bath Tradition include the following:

The symbol of the Andung-andung leaf which has been written seven verses of the Koran or Salamun Tujuh (Seven Welfare) and the water that has been prayed and the prayer that absorbs into the leaves of the Andung-andung and also absorbs into the human body when it is bathed. In addition, the meaning of Salamun Tujuh is adapted to the surah AlFatihah which consists of seven verses, as a symbol of the seven members of the human body that move and symbolize that the sky consists of seven layers.

The symbol of the pencil is the sign to write if there is no pencil, the writing is not visible.

Clean water (rain water or cooked water) has a symbol as a giver of life and absorbed by the human body. Not only that, the water used is using clean water, so clean water is a symbol of resignation to Allah SWT.

Besides that, there are meaning in reading the surah al-Ikhlas, al-Falak and an-Naas. The meaning of surah al-Ikhlas is that Allah is one, while surah al-Falak means that all evil is asking to keep away, keep away from the temptations of satan, and the meaning of surah anNaas is to drive away ethan or keep away from temptations.

The prayed water contains a symbol of effort and prayer by the Malay Community of Sungai Jambu Sub village in the month of Safar.

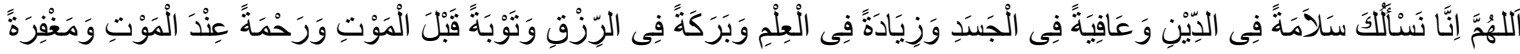

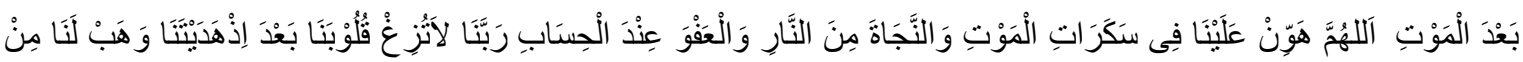

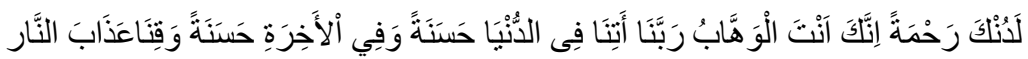

KHATULISTIWA: Journal of Islamic Studies

Vol. 8, No. 1. March 2018
DOI: 10.24260/khatulistiwa.v8i1.1278

Islam and Local Interests in The Safar bath Tradition

of Malays People in Sungai Jambu Sub Vilage, Kayong

Utara 
Meaning: "O Allah, we ask you for salvation in religion, and prosperity / freshness in the body and the addition of knowledge, and blessings, and repentance before death and mercy at death, and forgiveness after death. $O$ God, make it easy for us when we take our lives, survive the fire of hell and get forgiveness when charity is taken into account. $O$ God, do not shake our hearts after you give instructions and give us mercy from Your side. Surely You Are the Giver. a our Lord, give us the goodness of life in the world and the goodness of life in the hereafter, and keep us from the torment of hellfire.

The water has the symbol of preventing and cleansing from diseases in the month of Safar.

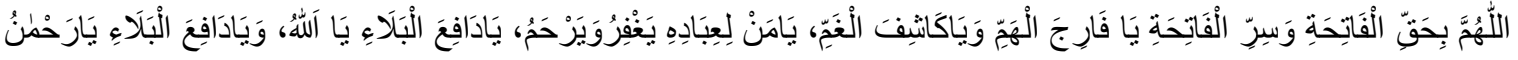

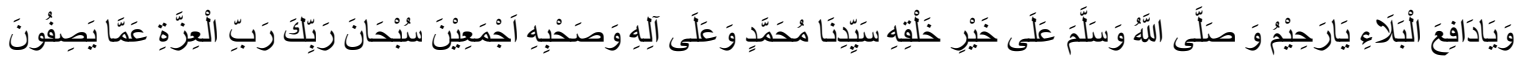

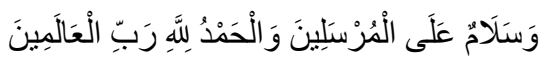

Meaning: " $O$ Allah, with fatihah truth and with the secrets contained in fatihah, $O$ God, the Lord who enlarges the position and Who removes sadness, $O$ God Almighty, compassion for his servant, $O$ Allah, God Who avoids reinforcements, $O$ God Dear God The one who rejects reinforcements, $O \mathrm{God}$, the Most Merciful Who keeps the reinforcements, reject from us catastrophes, calamities, disasters, abominations and mishaps, various disputes, cruelty and warfare, visible and hidden, in our country especially and in the state of the Muslims in general, you really have power over everything. "

Ketupat loose contains symbols of escaping from danger.

Furthermore, according to Mariana, a 34-year-old resident of Sungai Jambu Sub village stated that the Andung-andung leaves when written in the seven salamun verses were not easily destroyed, besides the width and hardness of the leaves. The meaning of the ketupat is a welcome to celebrate the salvation of the reinforcements in the month of Safar.

Based on the above opinion, the fact is that the Malay community of Sungai Jambu Sub village, Kayong Utara Regency considers the month of Safar as the month of bad luck and amulies. It is a tradition and preservation carried out for generations. If implemented, it will avoid disaster. Conversely, if it is not done, it is feared that it will be affected by an accident or disease. The tradition is only to be careful, so that the Malay community of Sungai Jambu Sub village preserves the Tradition of Mandi Safar with the intention of solely asking for protection in Allah SWT so that it will be protected from the Safar month.

\section{CONCLUSION}

The tradition of Safar bathing in the middle of the Malay community in Sungai Jambu Sub village, North Kayong, West Kalimantan is a form of self-approach to God carried out by the community. This tradition is a religious ceremony where people take lessons from the

KHATULISTIWA: Journal of Islamic Studies

Vol. 8, No. 1. March 2018
DOI: $10.24260 /$ khatulistiwa.v8i1.1278

Islam and Local Interests in The Safar bath Tradition

of Malays People in Sungai Jambu Sub Vilage, Kayong Utara 
disaster that befell the Prophet Muhammad sallallaahu 'Alaihi Wa Sallam, so that the local community believes that the month of Safar contains a lot of reinforcements.

To avoid reinforcements, a number of ways are taken, namely by jointly reciting the surah al-Fatihah, writing the verses found in surah Yasin (58), ash-Shafat (79), ash-Shafat (109), ash-Shafat (120), ash-Shafat (130), az-Zumar (73), al-Qadar (5) doing Salamun seven leaves soaked in water, recites prayer's, eat together, prayer is intended because of Bathing Safar because of Allah SWT and then doing the Safar Bath.

The Malay community of Sungai Jambu Sub village believes that the water that has been soaked with andung-danung leaves is used for bathing and as a medium to dissolve the reinforcements along with the flow of water from the tip of the head to a toe. Wednesday is a time where local people do Safar bath. Safar baths that are held every month in Safar were attended and attended by Malay people in Sungai Jambu Sub village men and women, elders and young people.

This tradition of Safar Bathing in society shows how Islam and local culture are integrated so that certain cultures can be implemented and gain legitimacy in society. The people's choice to pass on this tradition is because there are also positive values for their lives and the identity of the Sungai Jambu Malay community.

KHATULISTIWA: Journal of Islamic Studies

Vol. 8, No. 1. March 2018
DOI: $10.24260 /$ khatulistiwa.v8i1.1278

Islam and Local Interests in The Safar bath Tradition

of Malays People in Sungai Jambu Sub Vilage, Kayong Utara 


\section{BIBLIOGRAPHY}

Abdullah, I. (2009). Konstruksi dan Reproduksi Kebudayaan. Yogyakarta: Pustaka Pelajar.

Al-Banjary, AZ. ( 2015). Ceramah Agama Islam: Mitos Sial di Balik Bulan Safar.

Aibak, K. (2010). Fenomena Tradisi Megengan di Tulungagung. Millah: Jurnal Studi Agama, 10 (1), 69-86.

Albani, MN. (2006). Ringkasan Shahihul Muslim. Jakarta: Pustaka Azzam.

Wensinck, A. J. (1967). Concordance et Indices De La Tradition Musulmane, diterjemahkan ke dalam Bahasa Arab oleh Muhammad Fu“ ad „Abd. al-Baqy dengan judul al-Mu'jam alMufahras li Alfazh al-Hadits al-Nabawi.

Asbihani, A., \& Jalil, A. (2017). Eksistensi Tradisi Mandi Safar Di Desa Tanjung Punak Kecamatan Rupat Utara Kabupaten Bengkalis. Jurnal Online Mahasiswa Fakultas Ilmu Sosial dan Ilmu Politik Universitas Riau, 4(2), 1-14.

Arsyad, MA. (2005). Acara Ritual Mandi Safar Dan Syukuran Nelayan. Jambi. Dinas Kebudayaan dan Pariwisata Kab. Tanjabtim.

Bahtiar, L., Mursalin, A., \& Masburiah, M. Ritual Mandi Safar: Akulturasi Islam dan Tradisi Lokal: Studi Kasus di Desa Air Hitam Laut Kecamatan Sadu Kabupaten Tanjung Jabung Timur. Kontekstualita: Jurnal Penelitian Sosial Keagamaan, 23(2).

Chalik, A. (2016). Agama dan Politik dalam Tradisi Perayaan Rebo Wekasan. IBDA: Jurnal Kajian Islam dan Budaya, 14(1), 13-30.

Darwis, S. (2013). Bulan Safar yang Penuh Kebaikan dalam Nasihat Pekanan Insan Takaful. 13(1), 1-25

Hasan, R. (2012). Kepercayaan Animisme dan Dinamisme dalam Masyarakat Islam Aceh. MIQOT: Jurnal Ilmu-ilmu Keislaman, 36(2).

Khoiri, K. (2017). Antara Adat dan Syariat (Studi Tentang Tradisi Mandi Safar di Tasik Nambus, Riau, ditinjau dari Perspektif Islam). Jurnal Ilmiah Islam Futura, 16(2), 196210.

Marzuki, A. M. A. (2016). Nilai Pendidikan Islam dalam Tradisi Unan-unan Masyarakat Suku Tengger. Al Murabbi, 1(2), 217-242.

KHATULISTIWA: Journal of Islamic Studies

Vol. 8, No. 1. March 2018
DOI: $10.24260 /$ khatulistiwa.v8i1.1278

Islam and Local Interests in The Safar bath Tradition

of Malays People in Sungai Jambu Sub Vilage, Kayong Utara 
Mariana, N. (34). Warga Dusun Sungai Jambu Kabupaten Kayong Utara. Kamis, 5 Juli 2018 Pukul 19:07 WIB

Nadhiroh, W. (2017). Amalan di Hari Arba'mustamir Bulan Safar (Tradisi Membaca Doa Nabi Yunus "Lā Ilāha Illā Anta Subĥānaka Innī Kuntu min al-Zhālimīn” 2375 Kali pada Masyarakat Matang Ginalon Pandawan). SYAHADAH: Jurnal Ilmu Al-Qur'an \& Keislaman, 4(2).

Nurozi, A. (2016). Rebo Wekasan dalam Ranah Sosial Keagamaan di Kabupaten Tegal Jawa Tengah (Analisis Terhadap Ritual Rebo Wekasan di Desa Sitanjung Lebaksiu). AnNuha: Jurnal Kajian Islam, Pendidikan, Budaya \& Sosial, 3(1), 125-136.

Prasojo, Z.H. (2017). Ekosistem Agama dan Budaya dalam Komunitas Sungai Kapuas Atas Kalimantan Barat. Jurnal Al Albab, 6 (2): 2.

Faridah, S. (2015). Kepercayaan Masyarakat Banjar Terhadap Bulan Safar: Sebuah Tinjauan Psikologis. Al-Banjari: Jurnal Ilmiah Ilmu-Ilmu Keislaman, 11(1).

Sudardi, B., \& Ilafi, A. (2017). Hegemoni Budaya dalam Tradisi Manaqiban. Madaniyah, 7(1).

Sriyanto, A. (2015). Pengaruh Tradisi Lokal terhadap Wajah Keislaman Masyarakat Indonesia. Al-Mishbah: Jurnal Ilmu Dakwah dan Komunikasi, 9(1), 45-62.

Tobroni. (2012). Relasi Kemanusiaan dalam Keagamaan (Mengembangkan Etika Sosial Melalui Pendidikan). Bandung: CV Karya Putra Darwati.

Yusriadi. 2016a. Mencari Kearifan Lokal di Dabong. Pointer presentasi pada Seminar

BNPT Kalbar in Hotel Dangau, Singkawang, 24 November 2016.

Widjajaputra, B. (2008). Penyelenggaraan Pendidikan Berbasis Kearifan Lokal dan Hak-hak Anak. dalam Rambu-Rambu Pelaksanaan Pendidikan Berbasis Kearifan Lokal dan HakHak Anak (Bantul: SD Sendangsari).

\section{Interview with:}

Mu'in, A. (60 tahun). Sungai Jambu.

Abdul Hamid (55 tahun). Sungai Jambu.

Mariamah (65 tahun). Sungai Jambu.

KHATULISTIWA: Journal of Islamic Studies

Vol. 8, No. 1. March 2018
DOI: 10.24260/khatulistiwa.v8i1.1278

Islam and Local Interests in The Safar bath Tradition

of Malays People in Sungai Jambu Sub Vilage, Kayong Utara 